Journal of Lake Sciences, Vol. 10, Suppl., pp283-293,1998.

Copyright (C1998 by Science Press, Beijing.

Printed in P. R. China. All rights reserved.

\title{
The Measurement and Character of Sediment Denitrification Rates in Saginaw Bay, Lake Huron*
}

\author{
YANG Longyuan $^{1}$ and Wayne S. Gardner ${ }^{2}$ \\ ${ }^{I}$ Nanjing Institute of Geography and Limnology, CAS, Nanjing, 210008, China \\ ${ }^{2}$ National Oceanic and Atmospheric Administration, Great Lakes Environmental Research \\ Laboratory USA (Present address: The University of Texas at Austin Marine science Institute \\ 750 Chennalview Drive Port Aransas, Texas 78373,USA)
}

\begin{abstract}
It have been measured the denitrification rates (DR) of sediment in Saginaw Bay, Lake Huron, by $\mathrm{N}_{2}$ production method. Tripricate samples of sediment core were collected at two GLERL long-term monitoring sites of the Bay in July and August of 1995. The DR are 48.81 24.99 and 32.81-40.51 micromol $N_{2} m^{-2} h^{-1}$ in the Inner and Outer regions of Saginaw Bay, respectively.

The characters of DR in Saginaw Bay were studied also in this paper. The DR were influenced by the interactions between the Saginaw River as a main pollution source and the Lake Huron as a reservoir of high quality water. The impacts of zebra mussels (Dreissena Polymorpha) on denitrification in Saginaw Bay, Lake Huron, were discussed, Significant differences in $\mathrm{NH}_{4}^{+}$exchange fluxes were detected in the inner and outer bays. The molar ratios of $\mathrm{N}_{2}$ : TIN were similar at both sampling sites. Measured DR were positively correlated to $\mathrm{O}_{2}$ consumption rates in the headspace. Additionally, a negative correlation between $\mathrm{NH}_{4}^{+}$and $\mathrm{NO}_{3}{ }_{3}$ concentrations in the overlying water was found.
\end{abstract}

Keywords: Denitrification rate, Saginaw Bay, Zebra mussels

\section{Introduction}

Denitrification, the bacterial reduction of nitrate to nitrogen gas via nitrite, is an important nitrogen sink for available nitrogen in aquatic ecosystems. Nitrogen gas produced by denitrification can be directly exported into the atmosphere. The enriched nitrate loads may be greatly removed from tributaries or lakes in this way (Tomosyek et al. 1997). Previous investigations have documented that some environmental factors can stimulate or effect the denitrification rates between sediment-water interface. The concentration of oxygen, nitrogen oxides, organic carbon, $\mathrm{pH}$ value and temperature are important microenvironmental variables that influence natural denitrification rates (Geoering, 1985). For example, there are two main sources of nitrate as the reaction substrate of sediment denitrification. One is the nitrate diffusing

\footnotetext{
* Received 1997-02-25; accepted 1998-03-27.
} 
into the sediment from the water column. Another is the nitrate as the final product of nitrification in the sediment (Jenkins et al., 1984). Nielsen et al. (1990) have reported that the sediment denitrification rate caused by $\mathrm{NO}_{3}{ }^{-}$from the overlying water $\left(\mathrm{D}_{\mathrm{w}}\right)$ was proportional to the nitrate concentration. Andersen (1977) had found a positive correlation between denitrification rates in different lakes and the amount of oxygen uptaken by sediments. Recently, Rysgaard et al. (1996) have pointed out that changes in oxygen concentrations of the overlying water can effectively alter the penetration depth of $\mathrm{O}_{2}$ within the sediment. He also believed that $\mathrm{D}_{\mathrm{w}}$ is likely to depend on $\mathrm{NO}_{3}{ }^{-}$concentration in the overlying water as well as on the thickness of the oxide surface layer in the sediment if little $\mathrm{NO}_{3}{ }^{-}$is assimilated. Meanwhile, the impacts of benthic invertebrate on denitrification rates in sediments is of great importance to the fate of available nitrogen (Seitzinger, 1988). Zebra Mussels (Dreissena Polymorpha), as a heavily colonized benthic invertebrate in Laurention Grate Lakes recently years (Nalepa et al., 1995), impact palegic ecosystems by establishing high densities, filtering large volumes of water and removing particles ranging from $0.7 \mu \mathrm{m}$ up to $750 \mu \mathrm{m}$ in size. The filtering activity of zebra mussels can directly reduce concentrations of particulate nutrients. Meanwhile, the depletion of phytoplankton from the water column could indirectly reduce the internal production rates of nutrients such as nitrogen and phosphorus. The removal of phytoplankton and zooplankton in great quantity and transportation of these organic materials to the sediment surface by feces and pseudofeces could greatly modify the nutrient cycle pattern within the pelagic food web (Gardner et al., 1995). Additionally, large populations of zebra mussels usually excrete significant amounts of ammonium and phosphorus in the process of assimilation. These processes would lead to changes in pelagic microenvironmental parameters and alter the nitrification and denitrification rate of sediment cores (Gardner, et al., 1987). It is uncertain how the combination of these direct and indirect effects will alter nutrient cycling within the watersediment system in the Great Lakes. In this paper, denitrification rates of sediment at two sites representing contrasting trophic levels of Saginaw Bay, Lake Huron, were measured in the summer of 1995 . With the experimental results, the characteristics of denitrification rates, which may be highly impacted by the colonization of Zebra mussels are discussed.

\section{Methods}

\subsection{Description of the study sites}

Saginaw Bay is a shallow extension of Lake Huron, approximately $49 \mathrm{~km}$ in width and $80 \mathrm{~km}$ in length, with a drainage area of $21000 \mathrm{~km}^{2}$ (Smith, et al., 1977). The bay can be divided into two parts, the inner and the outer ones, on the basis of topography and trophic gradients. The Inner Saginaw Bay has a surface area of $1554 \mathrm{~km}^{2}$, with a mean water depth of $5.1 \mathrm{~m}$ and a water volume of $7.9 \mathrm{~km}^{3}$. The Outer Saginaw Bay has a surface area of $1217 \mathrm{~km}^{2}$, with a mean depth of $13.7 \mathrm{~m}$ and a volume of $16.6 \mathrm{~km}^{3}$ (Smith, et al., 1977). The water movement in Saginaw Bay follows a general counterclockwise pattern (Danek and Saylor, 1977), flowing in from Lake 
Huron along the north-eastern shore, mixing with Saginaw River water and flowing out along the south-western shore. However, this general circulation pattern is frequently altered by changes in wind direction (Schelske, et al., 1980). Most of the nutrients loaded into the bay are derived from the Saginaw River, which accounts for $70 \%$ of the total tributary flow into the bay (Chnale and Squire, 1975). Consequently, the inner bay is characterized by high levels of nutrients, suspended solids and phytoplankton biomass. The inner bay is a highly productive system that is influenced by inputs from the Saginaw River whereas the outer bay is less productive and influenced more by the nutrient-poor waters of Lake Huron (Dolan, et al., 1978).

Bottom substrates in Saginaw Bay range from silt to mostly cobble and rock. The inner bay has a wide sand-gravel bar extending from the Saginaw River to the Charity Islands along the eastern side of the bay. Another sand-gravel bar extends along the western shoreline to Point $\mathrm{Au}$ Gres. Both sand bars have irregular areas of cobble together with patches of sand, gravel, and pebbles (Nalepa, et al., 1995). It has been estimated that $70 \%$ of the bottom in the inner bay consists of sand, gravel and cobble, with about $30 \%$ consisting of silt / mud (Wood, et al., 1964). The area around the Charity Islands, on the eastern shore of the outer bay is rocky. Rock and clay were found near Point Lookout. Most of the offshore region of the outer bay has a bottom of silty sand.

\subsection{Experimental procedure}

\subsubsection{Sampling sites}

Triplicate sediment cores for denitrificaiton rate measurement and flow-through experiments were collected by divers on 27 June, 30 June, 1 August, and 3 August of 1995 from two GLERL monitoring sites in Saginaw Bay, Lake Huron. As shown in Fig. 1, Site 1 (Tawas Bay) is located in the outer bay near station $21\left(44^{\circ} 15^{\prime} \mathrm{N}, 83^{\circ} 30^{\prime} \mathrm{W}\right)$ while Site 2 is in the inner bay at station $5\left(43^{\circ} 56^{\prime} \mathrm{N}, 83^{\circ} 52^{\prime} \mathrm{W}\right)$. The two sampling sites are considered to represent the inner- and outer-bay environments, respectively. The water depths at Site 1 and Site 2 are $7.3 \mathrm{~m}$ and $3.7 \mathrm{~m}$. Both sites have sandy sediment except for the cores of Site 2 with a few fine clay particles.

The two sites represent contrasting trophic conditions and have different abundances of Zebra mussels. Site 1 is classified as oligotrophic and has typical chlorophyll values of $1-3 \mu \mathrm{g} \cdot \mathrm{L}^{-1}$, while Site 2 is mesotrophic and has a spring maximum chlorophyll level of $16 \mu \mathrm{g} \cdot \mathrm{L}^{-1}$ (Fahnenstiel, et al., 1995). Zebra mussels were abundant (more than 4000 individual per square meter) at Site 2 but were not found at Site 1 (Nalepa, et al., 1995).

\subsubsection{Analysis of gas sample and nitrogen ions}

$\mathrm{N}_{2}$ and $\mathrm{O}_{2}$ gases were analyzed with a Shimadzu gas chromatography (model GA-8A) equipped with dual Molecular Sieve (5A) columns, a thermal conductivity detector and a gastight sampling syringe. A special vessel was installed on the syringe to prevent contamination from the atmosphere during the process of continuously flushing with helium gas. The details of 
gas sampling and analysis are given in Gardner et al. (1987), Seitzinger et al. (1980), and Tomaszek et al (1997).

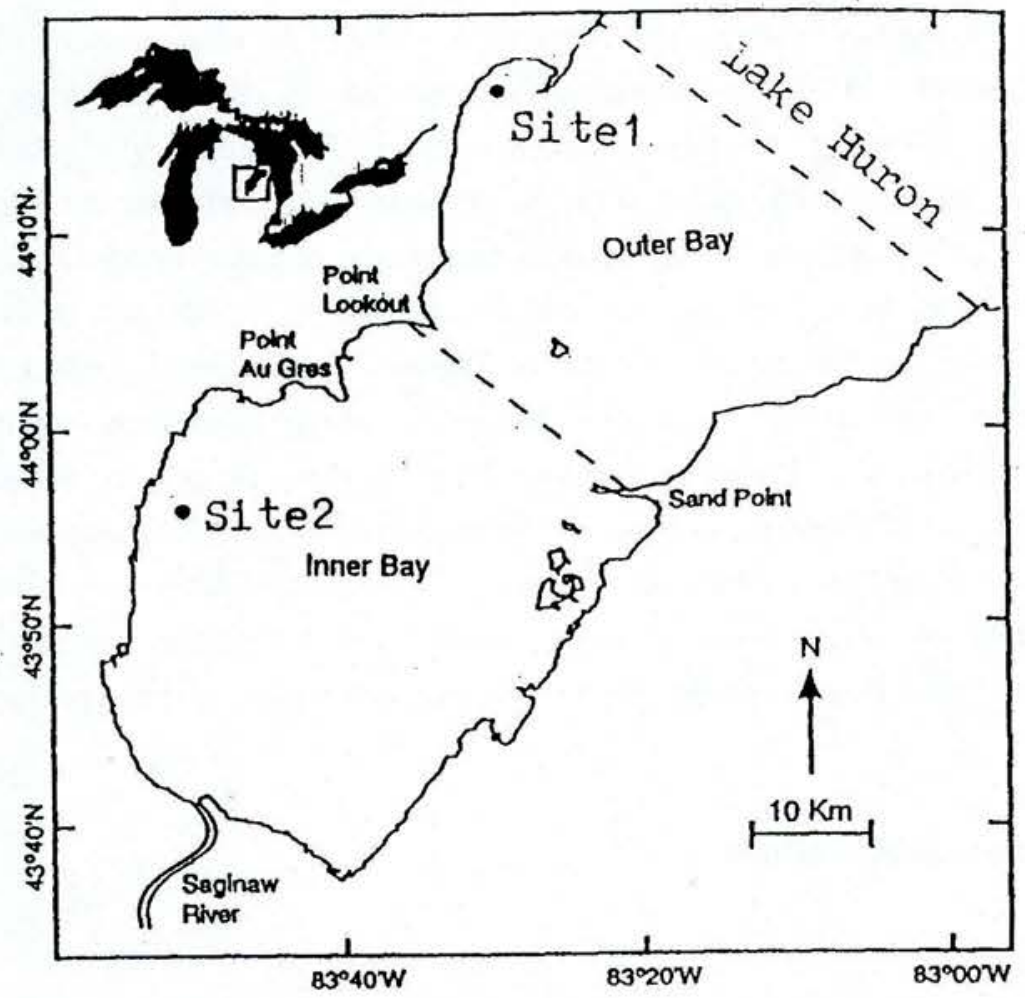

Fig. 1 The Topographical shape of Saginaw Bay, Lake Huron, and the location of sampling sites

After particles were removed from the water samples that were collected from gas-tight chamber incubations, ammonium concentrations were measured by discrete injection HPLC techniques (Gardner, 1991). Nitrate plus nitrite concentrations were measured with automated colorimetric techniques with Auto Analyzer (APHA, 1990), respectively, as described by Davis and Simmons (1979).

\subsubsection{Measurement of denitrification rates with incubation in gas-tight chamber}

Denitrification rates of sediment cores were quantified directly by measuring the concentrations of $\mathrm{N}_{2}$ gas that accumulated in the headspaces of gas-tight incubation chambers (Seitzinger, 1980). Each chamber was equipped with a single, vertical stopcock for purging the microcosm with $\mathrm{He}-\mathrm{O}_{2} \quad(80 \%: 20 \%)$ gas and withdrawal of samples of gas and water (Gardner et al, 1987). A suspended magnetic bar stirred the overlying water in the course of incubation to enhance gas diffusion and equilibration.

Intact upright sediment cores were collected and brought to the laboratory in an ice chest. The lower part of each sample sediment core was extruded by gravity and discarded. After the upper 
$60-70 \mathrm{~mm}$ of a sediment core with overlying water was gently put into the lower section of a gas-tight glass chamber (76 mm i.d.), and the upper section of the chamber was attached and sealed via a metal clamp. The gas-tight chamber with the clamp was weighed. Then, each chamber was fully filled with lake water and weighed again to determine the water volume. Sixty $\mathrm{ml}$ of water was removed from each chamber by syringe to leave an exact volume of the headspace gas phase. After the water and gas phase were sparged for $1 \mathrm{~h}$ with $\mathrm{He}-\mathrm{O}_{2}$ gas to remove atmospheric $\mathrm{N}_{2}$, each chamber was placed in an incubator equipped with an overhead magnetic stirring apparatus for continuously driving the magnetic stirrers inside the chambers. All the stirrers were rotated at a speed of $60 \mathrm{rpm}$. The incubation temperature was adjusted to in situ temperature $\left(22^{\circ} \mathrm{C}\right)$. The incubation time was 1 hour. This sparging procedure was repeated 7 times daily for 4 days to replace the nitrogen gas diffusing from sediment samples with helium (Tomaszek, et al. in press). Then the nitrogen and oxygen concentrations in the headspace were measured with gas chromatography over incubation periods of 1-2 days to provide a time course measurements (Seitzinger, 1980).

In sampling, the open end of the vertical stopcock installed on the gas-tight chamber was continuously flushed with $\mathrm{He}-\mathrm{O}_{2}$ to prevent contamination from atmospheric nitrogen and oxygen. Volume changes of the water and gas phases, as a result of water sampling, were taken into account in the flux calculations. To sample the headspace gas, an inlet cannula from the gassampling valve was installed at the open end of the vertical stopcock. Before sampling, the syringe was flushed for several times with helium. Five tenth $\mathrm{ml}$ of gas was collected with the sampling syringe. Then the gas sample was injected and analyzed immediately.

Following gas sampling, water samples $(6 \mathrm{ml})$ were removed with a syringe equipped with a long cannula and filtered $(0.2 \mu \mathrm{m}$ pore size nylon fitter $)$. Part of the water sample was used for ammonium analysis with HPLC (Gardner, 1991). The remainder was frozen for nitrate / nitrite analysis with Auto Analyzer (APHA, 1990).

After gas and water sampling, each chamber was flushed again with $\mathrm{He}_{-} \mathrm{O}_{2}$ gas in preparation for the next measurement. The water-sediment core was flushed with $\mathrm{He}$ gas only instead of He$\mathrm{O}_{2}$ gas to measure the background concentration of nitrogen gas at the end of experiment.. Without $\mathrm{O}_{2}$ in the gas-tight chambers, the denitrification process was stopped. The $\mathrm{N}_{2}$ concentration value which was measured over the $\mathrm{He}$ flushed water-sediment core was considered to represent the background flux of the system. The denitrification rates samples were calculated by substracting the background value of $\mathrm{N}_{2}$ fluxes from the $\mathrm{N}_{2}$ production fluxes.

\section{Results and discussion}

\subsection{Analytical results of gas-tight chamber incubations}

The denitrification rates in summer of 1995 at Saginaw Bay, Lake Huron varied between 16.0 and $39.6 \mu \mathrm{mol} \mathrm{N} \cdot \mathrm{m}^{-2} \cdot \mathrm{h}^{-1}$ (Tab. 1). It is clear from Tab. 1 that the average temporal variation range of denitrification rates at Site 1 is smaller than the one at Site 2. While no fluxes 
of ammonium were detected in July and August at Site 2, the average ammonium flux at Site 1 was relatively high. The flux ratio of $\mathrm{O}_{2}$ consumption rate to $\mathrm{N}_{2}$ production rate at both sites were about 47:1 in July. However, the flux ratio of $\mathrm{O}_{2}: \mathrm{N}_{2}$ at Site 1 and Site 2 in August were reduced to $29: 1$ and 20:1, respectively.

\subsection{Effects of coupling activity on denitri-fication rates}

The denitrification rates measured at Site 1 in July and August, 1995 varied from $23 \mu \mathrm{mol}$ $\mathrm{N}_{2} \cdot \mathrm{m}^{-2} \cdot \mathrm{h}^{-1}$ to $26 \mu \mathrm{mol} \mathrm{N}_{2} \cdot \mathrm{m}^{-2} \cdot \mathrm{h}^{-1}$, while the simultaneously measured rates at Site 2 varied from $16 \mu \mathrm{mol} \mathrm{N} \mathrm{N}_{2} \cdot \mathrm{m}^{-2} \cdot \mathrm{h}^{-1}$ to $40 \mu \mathrm{mol} \mathrm{N} \mathrm{N}_{2} \cdot \mathrm{m}^{-2} \cdot \mathrm{h}^{-1}$. To compare the denitrification rate measured in July with that in August, the ratios of the rates were calculated. The ratios of August rates to July rates at Site 1 and Site 2 were 1.1 and 2.5 , respectively. It is clear that the temporal variation of denitrification at the outer bay of Saginaw Bay was smaller than that at the inner bay. This phenomenon could be explained by the effect of coupling activity of Saginaw River and Lake Huron.

The Saginaw Bay is terrestrially connected via the Saginaw River (Fig. 1). Most of the nutrients loaded to the Saginaw Bay are derived from this polluted river. Consequently, the inner bay is characterized by high levels of nutrients, suspended solids and phytoplankton biomass (Dolan et al., 1978) and has serious seasonal problems in water quality. The nitrification and denitrification rates in active microenvironments are controlled by the availability of substrates, which are supplied by diffusion along concentration gradients to a large extent (Nielsen, et al., 1990). Processes that alter these gradients will therefore affect both nitrification and denitrification. Thus, the influences of the Saginaw River may contribute to the high temporal variability of denitrification rates of sediment in the inner bay. On the contrary, since the outer bay is more directly connected with Lake Huron, that is relatively unpolluted, its water quality is affected by Lake Huron more than by the Saginaw River. The environmental parameters which may affect the nitrification and denitrification processes in the sediment cores are relatively stable. Therefore, the range of denitrification rates measured in the outer bay is smaller than that in the inner bay.

\subsection{Ecological effect of zebra mussels on denitrification rates of sediment}

Zebra mussels (Dreissena Polymorpha), as a heavily colonized benthic invertebrate in Laurention Grate Lakes recently years (Nalepa et al., 1995), were abundant at Site 2 but not found at Site 1 (Nalepa et al., 1995). The differences in spatial distribution of Zebra mussels populations between the two regions of the Saginaw Bay can cause significant impacts on aquatic ecosystems. Large populations of zebra mussels usually excrete significant amounts of ammonium and phosphorus in the process of assimilation. These processes would lead to changes in pelagic microenvironmental parameters and alter the nitrification and denitrification rate of sediment cores (Gardner et al., 1987). For example, zebra mussels impact palegic ecosystems by establishing high densities, filtering large volumes of water and removing 
particles ranging from $0.7 \mu \mathrm{m}$ up to $750 \mu \mathrm{m}$ in size. The filtering activity of zebra mussels can directly reduce concentrations of particulate nutrients. Meanwhile, the depletion of phytoplankton from the water column could indirectly reduce the internal production rates of nutrients such as nitrogen and phosphorus. The removal of phytoplankton and zooplankton in great quantity and transportation of these organic materials to the sediment surface by feces and pseudofeces could greatly modify the nutrient cycle pattern within the pelagic food web (Gardner et al., 1995). From the data measured in the whole experimental period, an interesting phenomenon on $\mathrm{NH}_{4}{ }^{+}$exchange fluxes could be found. The experimental data shows that minimal $\mathrm{NH}_{4}{ }^{+}$exchange could be detected in the inner bay both in July and August. The measured fluxes of $\mathrm{NH}_{4}{ }^{+}$released from the sediment core to the overlying water were -5.37 and $1.1 \mu \mathrm{mol} \cdot \mathrm{m}^{-2} \cdot \mathrm{h}^{-1}$ in July and August, respectively. In contrast, the $\mathrm{NH}_{4}{ }^{+}$exchange fluxes measured in the outer bay were relatively high at $17.3 \mu \mathrm{mol} \cdot \mathrm{m}^{-2} \cdot \mathrm{h}^{-1}$ and $24.2 \mu \mathrm{mol} \cdot \mathrm{m}^{-2} \cdot \mathrm{h}^{-1}$ in July and August, respectively (Table 1).

\section{Tab.1 The analytical results of Gas-tight chamber incubation}

\begin{tabular}{llcccc}
\hline Month & Component & Flux of Site $1\left(\mu \mathrm{mol} \cdot \mathrm{m}^{-2} \cdot \mathrm{h}^{-1}\right)$ & $\mathrm{SE}$ & Flux of Site $2\left(\mu \mathrm{mol} \cdot \mathrm{m}^{-2} \cdot \mathrm{h}^{-1}\right)$ & $\mathrm{SE}$ \\
\hline July & $\mathrm{O}_{2}{ }^{*}$ & 1069 & 105 & 752 & 22 \\
& $\mathrm{~N}_{2}{ }^{* *}$ & 22.7 & 9.9 & 16.0 & 3.4 \\
& $\mathrm{NH}_{4}{ }^{* * * *}$ & 17.32 & 14 & -5.4 & 6.1 \\
& $\mathrm{NO}_{3}{ }^{*}{ }^{* * * *}$ & 19.1 & 6.7 & 14.2 & 8.1 \\
August & $\mathrm{O}_{2}{ }^{*}$ & 768 & 42 & 802 & 38 \\
& $\mathrm{~N}_{2}{ }^{* *}$ & 26.1 & 5.5 & 39.6 & 4.4 \\
& $\mathrm{NH}_{4}{ }^{* * * *}$ & 24.2 & 11.2 & 1.1 & 5.1 \\
& $\mathrm{NO}_{3}{ }^{* * * *}$ & 12.6 & 4.1 & 19.1 & 3.6 \\
\hline
\end{tabular}

$* \mathrm{O}_{2}$ flux was given as consumption rate was measured by gaschromatography (GC); ** $\mathrm{N}_{2}$ concentration was measured with $\mathrm{GC} ; * * * \mathrm{NH}_{4}{ }^{+}$concentration was measured with HPLC; $* * * * \mathrm{NO}_{3}{ }^{-}$concentration was measured with automated colorimetric techniques on Auto Analyzer II.

The differences of $\mathrm{NH}_{4}{ }^{+}$concentration on supply rates between the inner and the outer bay, which were affected by the different abundance of zebra mussel, may result in different nitrification/ denitrification rates. In addition to nutrient excretion, zebra mussels can alter the dynamics of nutrient cycling and biochemical energy flow by selectively affecting sediment components and by high filtering capacity. They may also affect nitrification rates by removing grazers of nitrifying bacteria (Lavrentyev, et al. 1997). This phenomenon was examined in core flow-through experiments by examining differences in microbial food web composition between inlet and outlet waters. The results are reported in a companion paper (Lavrentyev, et al., In review).

\section{4 $\mathrm{N}_{2}$ : TIN flux ratio}

The experimental data in table 2 shows the ratios of $\mathrm{N}_{2}$ production rates, i.e. denitrification rates, to the sum of flux or total inorganic nitrogen compounds (TIN) including $\mathrm{N}_{2}, \mathrm{NO}_{3}{ }^{-}$and 
$\mathrm{NH}_{4}{ }^{+}$, measured in the gas-tight chambers collected from the inner and outer bays remain a constant. The ratios of $\mathrm{N}_{2}$ :TIN flux measured at Site 1 in July and August are 0.38 and 0.41 respectively, while the simultaneously measured ratios at Site 2 are 0.65 and 0.66 . The average value of the later site is about 1.7 times higher than that of the former one. The reason for the temporally constant $\mathrm{N}_{2}$ :TIN flux ratio may be due to the stable properties of the sediment cores taken from each site. It is a microcosms inside the gas-tight chamber in the course of measuring sediment denitrification rates with $\mathrm{N}_{2}$ production method. Since the sediment-water cores inside the chambers were isolated from the outer environment during incubation periods, no exchanges of gas or ion between the inside and outside of chambers happened. So after a long time, usually more than $12 \mathrm{~h}$, of incubation, a biochemical equilibrium was established in the microcosms inside of those chambers. According to the denitrification reaction:

$\left(\mathrm{CH}_{2} \mathrm{O}\right)_{106}\left(\mathrm{NH}_{3}\right)_{16} \mathrm{H}_{3} \mathrm{PO}_{4}+84.8 \mathrm{HNO}_{3}=106 \mathrm{CO}_{2}+16 \mathrm{NH}_{3}+\mathrm{H}_{3} \mathrm{PO}_{4}+42.4 \mathrm{~N}_{2}+48.4 \mathrm{H}_{2} \mathrm{O}$

Tab.2 The $\mathrm{N}_{2}$ :TIN flux ratios in sediment cores of Saginaw Bay

\begin{tabular}{lllllll}
\hline & \multicolumn{2}{l}{ Site $1\left(\mu \mathrm{mol} \mathrm{N}_{2} \cdot \mathrm{m}^{-2} \cdot \mathrm{h}^{-1}\right)$} & \multicolumn{4}{l}{ Site $2\left(\mu \mathrm{mol} \mathrm{N}_{2} \cdot \mathrm{m}^{-2} \cdot \mathrm{h}^{-1}\right)$} \\
Month & $\mathrm{N}_{2}$ & TIN & Ratio & $\mathrm{N}_{2}$ & TIN & Ratio \\
\hline July & 22.7 & 59.1 & 0.38 & 16.0 & 24.8 & 0.65 \\
August & 26.1 & 62.9 & 0.41 & 39.6 & 59.7 & 0.66 \\
\hline
\end{tabular}

The concentrations of products $\mathrm{NH}_{3}, \mathrm{NH}_{4}{ }^{+}$and $\mathrm{N}_{2}$ should be constant at the equilibrium status. It may theoretically account for the observed constant $\mathrm{N}_{2}$ : TIN ratio. This interest phenomenon should be more examined in the future work.

\subsection{The relationship of $\mathrm{O}_{2}-\mathrm{N}_{2}$ and $\mathrm{NH}_{4}{ }^{+}-\mathrm{NO}_{3}{ }^{-}$fluxes}

Some relationships between the compounds which are relevant to denitrification reaction in sediments have been reported in documents. Nielsen et al. (1990) reported that the sediment denitrification rate caused by $\mathrm{NO}_{3}{ }^{-}$from the overlying water $\left(\mathrm{D}_{\mathrm{w}}\right)$ was proportional to the nitrate concentration. Andersen (1977) had found a positive correlation between denitrification rates in different lakes and the amount of oxygen uptaken by sediments. Rysgaard et al. (1994) have pointed out that changes in oxygen concentrations of the overlying water can effectively alter the penetration depth of $\mathrm{O}_{2}$ within the sediment. He also believed that water column denitrification is likely to depend on $\mathrm{NO}_{3}$ concentration in the overlying water as well as on the thickness of the oxide surface layer in the sediment if little $\mathrm{NO}_{3}{ }^{-}$is assimilated. Do the increases of oxygen consumption rate result in increases of denitrification rates? Is there any relationship between the $\mathrm{NO}_{3}{ }^{-}$and $\mathrm{NH}_{4}{ }^{+}$? From the data of incubation experiments designed for measuring denitrification rates of sediment, some interesting relationships between $\mathrm{O}_{2}$ consumption and $\mathrm{N}_{2}$ production and between $\mathrm{NH}_{4}{ }^{+}$and $\mathrm{NO}_{3}{ }^{-}$concentrations were found.

As Fig. 2 shows, the denitrification rates of sediments proportionally increase versus oxygen consumption rates during the incubation periods. The reason may be explained with the 
denitrification reaction (1) which occurs within the sediment layer under anaerobic condition. When the amount of $\mathrm{O}_{2}$ penetrated from the overlying water to the sediment raises relative to incubation time, the concentration of $\mathrm{NO}_{3}{ }^{-}$produced in nitrification also raises. So according to the reaction (1) more $\mathrm{N}_{2}$ gas as a result of denitrification could be emitted to the headspace. In the contrary cases, little $\mathrm{N}_{2}$ gas could be released. As shown in Fig. 2, even though the correlation coefficient is small (Relationship coefficients are between 0.4-0.65.), the positive correlation between $\mathrm{O}_{2}$ consumption rates and dinitrification rates is still obvious.

Fig. 3 shows the $\mathrm{NH}_{4}{ }^{+}$fluxes from the sediments to the overlying water decreased while the $\mathrm{NO}_{3}^{-}$fluxes increased versus the incubation time. After about $350 \mathrm{~h}$ when the $\mathrm{NH}_{4}{ }^{+}$fluxes became negative, the $\mathrm{NH}_{4}^{+}$concentrations in the overlying water started to decline. It means that the $\mathrm{NH}_{4}{ }^{+}$ions started to diffuse into the sediments from the overlying water. On the contrary, the $\mathrm{NO}_{3}{ }^{-}$exchange fluxes were very small at the beginning period of incubation. But with longer incubation time, $\mathrm{NO}_{3}^{-}$ions started to diffuse into overlying water from the sediments and $\mathrm{NO}_{3}{ }^{-}$exchange fluxes gradually became stable. In the outer bay, the stable $\mathrm{NO}_{3}$. flux in July and August was 33.7 and 27.2 $\mu \mathrm{mol} \cdot \mathrm{m}^{-2} \cdot \mathrm{h}^{-1}$, respectively. Such variation of $\mathrm{NO}_{3}{ }^{-}$and $\mathrm{NH}_{4}{ }^{+}$and their relationships may be due to the coupling impacting of nitrification and denitrification in the sediment.

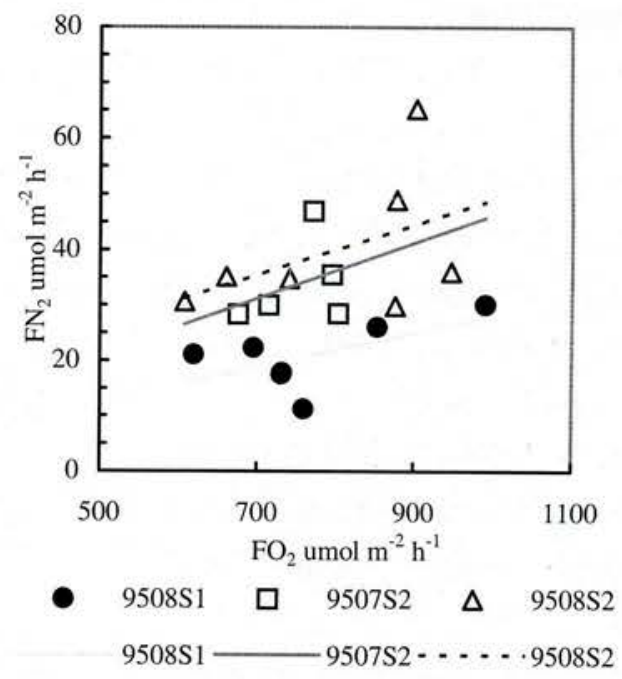

Fig.2 The trendlines between denitrification rates and oxygen consumption rates. (9508S2: Site 2, August of 1995; 9507S2: Site 2, July of 1995; 9508S1: Site 1, August of 1995.)
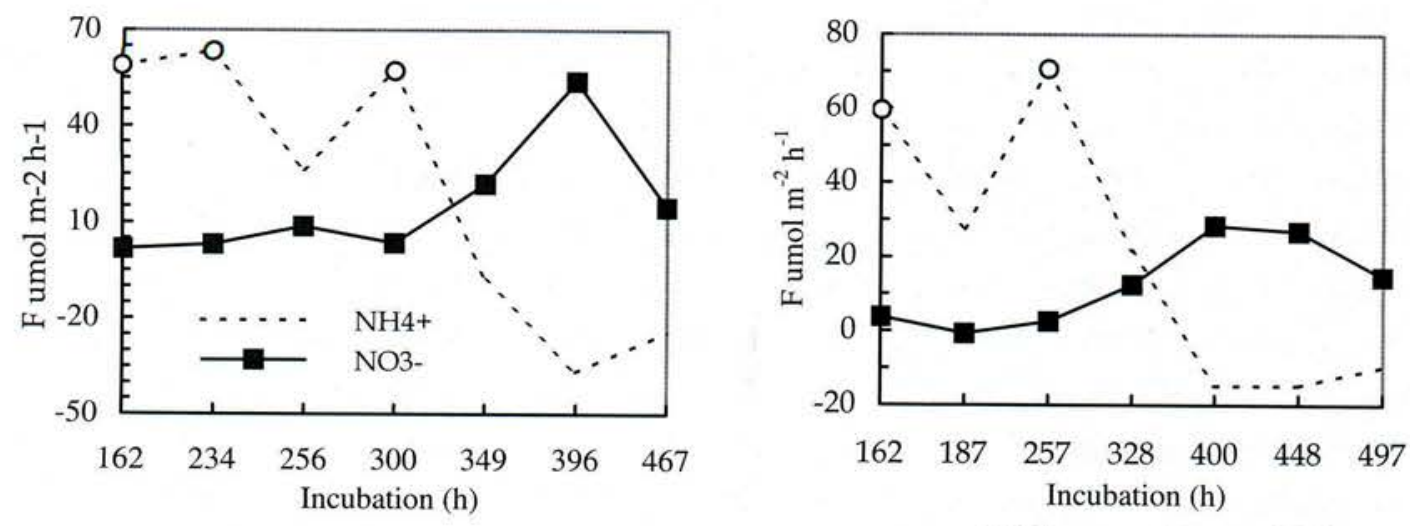

.... $\mathrm{NH} 4+\longrightarrow$ NO3-

Fig.3 The negative relationship between $\mathrm{NH}_{4}{ }^{+}$and $\mathrm{NO}_{3}{ }^{-}$ions in the incubation time course

at site1. Left: July of 1995, $r=-0.8266 ; \quad$ Right: August of 1995, $r=-0.7133$. 


\section{Acknowledgements}

We should thank J. R. Johnson, J. F. Cavaletto, and T. H. Johengen for their help in the laboratory work. We have to acknowledge the National Oceanic and Atmospheric Administration, Great Lakes Environmental Research Laboratory for providing apparatus and facilities for the experiments and the Chinese Ecosystem Research Network, Chinese Academy of Sciences for financially supporting this co-operation.

\section{References}

Andersen, J. M. 1977. Rates of denitrification of undisturbed sediment from six lakes as a function of nitrate concentration, oxygen and temperature. Arch. Hydrobiol. 80: 147.

APHA. 1990. Standard methods for the examinstion of water and waste water, 17th edition. American Public Health Association, Washington, D.C.

Canale, R. P., and Squire, J. 1976. A model for total phosphorus in Saginaw Bay, Lake Huron. J. Great Lakes Research.2: 364-373.

Danek, L. J., and Saylor, J. H. 1977. Measurement of the summer currents in Saginaw Bay, Lake Huron. J. Great Lakes Res.3: 65-71.

Davis, C. O., and Simmons, M. S. 1979. Water chemistry and phytoplankton field and laboratory procedures. Special Report No. 70, Great Lakes Research Div. Univ. of Michigan, Ann Arbor, MI.

Dolan, D. M. et al. 1978. Statistical analysis of the spatial and temporal variability of the ratio chlorophyll a to phytoplankton cell volume in Saginaw Bay, Lake Huron. J. Great Cakes Res., 4: 75-83.

Fanenstiel, G. L. et al.1995. Effects of zebra mussel (Dreissena Polymorpha) colonization on water quality parameters in Saginaw Bay, Lake Huron. J. Great Lakes Research.21:435-448.

Gardner, W. S. and Scavia, D. 1981. Kinetic examination of nitrogen release by zooplankters. Limonl. \& Oceanogr. 26: 801-810.

Gardner, W. S. et al.1987. Nitrogen mineralization and denitrification in Lake Michigan sediments. Limonl.\& Oceanogr. 32: 1226-1238.

Gardner, W. S. 1991. High-Performance Liquid Chromatographic method to determine ammonium ion and primary amines in seawater, Anal. Chemi.63: 537-540.

Gardner, W. S. et al. 1995. Effects of the zebra mussel, Dreissena Ploymorpha, on community nitrogen dynamics in Saginaw Bay, Lake Huron. J. Great Lakes Research.21: 529-544.

Georing, J. J. 1985. Marine denitrification. In 'Denitrification in the nitrogen cycle', ed. H.L. Golterman, Plenum Press, New York. pp. 191-224.

Griffiths, R. W. 1993. Effects of zebra mussels (Dreissena Polymorpha) on the benthic fauna of Lake St. Clair. In 'Zebra Mussels: Biology, impacts, and control', ed. By T.F. Nalepa and D.E. Schloesser, Boca Raton, FL: Leqis publishers/ CRC Press. pp. 415-437.

Jenkins, M. C. et al. 1984. The coupling of nitrification in two estuarine sediments, Limnol. 
Oceanogr. 29: 609-619.

Kryger, J. and Riisgard, H.U. 1988. Filtration rate capacities in 6 species of European freshwater bivalves, Qecologia.77: 34-38.

Lavrentyev, P. J. et al. 1995. Effects of the zebra mussel ( Dreissena Polymorpha Pallas ) on protozoa and phytoplankton from Saginaw Bay, Lake Huron, J. Great Lakes Res. 21: 545-557.

Nalepa,T. F.et al. 1995. Initial colonization of the zebra mussel (Dreissena Polynorpha) in Sginaw Bay, Lake Huron: population recruitment, density, and size structure. J. Great Lakes Res. 21:417-434.

Nielsen, L. P.et al. 1990. Denitrification and photosynthesis in stream sediment studied with microsensor and wholecore techniques. Limnol. Oceanogr.35: 1135-1144.

Rysgaard, S. et al. 1994. Oxygen regulation of nitrification and denitrification in sediments, Limnol. Oceanogr.39: 1643-1652.

Schelske, C. L. et al. 1980. Limnological conditions in southern Lake Huron, 1974 and 1975. EPA Report No. 600/3-80-125, U.S. Envbironmental Protection Agency, Duluth, MN.

Seitzinger, S. et al.1980. Denitrification and $\mathrm{N}_{2} \mathrm{O}$ production in near-shore marine sediments. Geochemica et Cosmochimica Acta.44: 1853-1860.

Smith, V. E. et al. 1977. Survey of chemical factors in Saginaw Bay, Lake Huron, EPA Report No. 600/3-7-125, Environmental Protecton Agency, Duluth, MN.

Tomaszek, J. A. et al. 1997. Denitrification in sediments of a Lake Erie coastal wetland (Old Woman Creek, Huron, Ohio, U.S.A ), J. Great Lakes Res. 23: 403-415.

Wood, L. E. 1964. Bottom sediments of Saginaw Bay, Michigan. J. Sediment Petrol.34: 173-184. 